\title{
The impact of the 2009 influenza $A(\mathrm{H} 1 \mathrm{~N} 1)$ pandemic on attitudes of healthcare workers toward seasonal influenza vaccination 2010/11
}

C Brandt ${ }^{1}$, H F Rabenau ${ }^{2}$, S Bornmann³ , R Gottschalk ${ }^{4}$, S Wicker (sabine.wicker@kgu.de)5

1. Institute of Medical Microbiology and Infection Control, Hospital of the Johann Wolfgang Goethe-University, Frankfurt, Germany

2. Institute of Medical Virology, Hospital of the Johann Wolfgang Goethe-University, Frankfurt, Germany

3. Institute of Occupational, Social and Environmental Medicine, Friedrich-Schiller-University, Jena, Germany

4. Health Protection Authority, City of Frankfurt am Main, Frankfurt, Germany

5. Occupational Health Service, Hospital of the Johann Wolfgang Goethe-University, Frankfurt, Germany

Citation style for this article:

Brandt C, Rabenau HF, Bornmann S, Gottschalk R, Wicker S. The impact of the 2009 influenza A(H1N1) pandemic on attitudes of healthcare workers toward seasonal influenza vaccination $2010 / 11$.

Euro Surveill. 2011;16(17):pii=19854. Available online: http://www.eurosurveillance.org/ViewArticle.aspx?Articleld=19854

This article has been published on 28 April 2011

The emergence of the influenza $A\left(\mathrm{H}_{1} \mathrm{~N}_{1}\right)_{2} 009$ virus provided a major challenge to health services around the world. However, vaccination rates for the public and for healthcare workers (HCWs) have remained low. We performed a study to review the reasons put forward by HCWs to refuse immunisation with the pandemic vaccine in 2009/10 and characterise attitudes in the influenza season 2010/11 due to the emergence of influenza $A\left(\mathrm{H}_{1} \mathrm{~N}_{1}\right) 2009$. A survey among HCWs and medical students in the clinical phase of their studies was conducted, using an anonymous questionnaire, at a German university hospital during an influenza vaccination campaign. 1,366 of 3,900 HCWs $(35.0 \%)$ were vaccinated in the $2010 / 11$ influenza season. Of the vaccinated HCWs, 1,323 (96.9\%) completed the questionnaire in addition to 322 vaccinated medical students. Of the 1,645 vaccinees who completed the questionnaire, 712 had not been vaccinated against the influenza $A\left(\mathrm{H}_{1} \mathrm{~N}_{1}\right) 2009$ virus in the $2009 / 10$ season. The main reason put forward was the objection to the ASo3 adjuvants (239/712, 33.6\%). Of the HCWs and students surveyed, 270 of 1,645 (16.4\%) stated that the pandemic had influenced their attitude towards vaccination in general. Many German HCWs remained unconvinced of the safety of the pandemic (adjuvanted) influenza vaccine. For this reason, effective risk communication should focus on educating the public and HCWs about influenza vaccine safety and the benefits of vaccination.

\section{Introduction}

Healthcare workers (HCWs) are at risk of occupational exposure to influenza and when infected, may transmit the disease to vulnerable patients [1-3]. The most important prevention strategy is immunisation [4]. However, despite official recommendations, e.g. from the World Health Organization (WHO), the European Union [5] and the Robert Koch Institute (RKI) in Germany, and the availability of a safe effective and well-tolerated vaccine, acceptance of seasonal influenza vaccine among HCWs is problematic and leads to low coverage, as detailed in many studies from all over of the world [6-10].

High influenza vaccination rates among HCWs can reduce the spread of influenza in healthcare facilities and help maintain a sustainable and effective healthcare workforce. Rumours and fears such as 'the vaccine does not work' or 'the vaccine causes flu' about a vaccine for which substantial health-related and economic benefits have been demonstrated also for healthy adults, should not hinder vaccination of HCWs because this ultimately compromises patient safety and public health $[11,12]$.

During the influenza $A\left(\mathrm{H}_{1} \mathrm{~N}_{1}\right)$ pandemic in 2009/10 many HCWs worldwide expressed concerns about the safety of the monovalent pandemic vaccine and refused to receive it because it was a 'new' vaccine, 'untested', and 'rushed to the market' [13]. For most, the infection with influenza $\mathrm{A}\left(\mathrm{H}_{1} \mathrm{~N}_{1}\right)_{2} 2009$ virus turned out to be less severe than first feared, however, severe disease and deaths occurred not only in the traditional risk groups for influenza but also in healthy young people and pregnant women [14]. However, if the virus had been more pathogenic and virulent, the impact of the pandemic could have been devastating [13].

A population of vaccinated, working and informed HCWs is crucial for an effective response to the burden of influenza and the mitigation of the associated morbidity and mortality [15]. Although we do not know which influenza virus subtype will cause possible future pandemics, a number of lessons can be learned from the influenza $A\left(\mathrm{H}_{1} \mathrm{~N}_{1}\right) 2009$ pandemic in 2009/10. Healthcare organisations and policy makers need to 
rethink current practices and ought to wonder whether voluntary influenza immunisation programmes for HCWs, which do not lead to satisfactory vaccination rates, are adequate to protect patient safety with regards to both seasonal and pandemic influenza $[11,16]$.

The influenza $\mathrm{H}_{1} \mathrm{~N}_{1} / 09$ pandemic was discussed with HCWs of the university hospital Frankfurt for the first time in July 2009, when the first cases became hospitalised. In order to prevent transmission, HCWs caring for patients with respiratory symptoms were obliged to wear a surgical mask. Moreover, HCWs were instructed to wear a FFP2 mask during direct contact with a patient with laboratory confirmed 2009 pandemic influenza $A\left(\mathrm{H}_{1} \mathrm{~N}_{1}\right)$ when they had not been vaccinated against the relevant virus. The pandemic vaccine became available from 26 October, 2009. The uptake of the pandemic vaccination at the university hospital Frankfurt was $36.3 \%$ in the $2009 / 10$ season.

We conducted a cross-sectional study to characterise the reasons why HCWs vaccinated against influenza in $2010 / 11$ had refused the pandemic vaccine in 2009/10 at a time when it was unclear how the pandemic would unfold. Further, we evaluated their attitudes towards the pandemic. In this paper, we describe why the results support the need for well-defined risk communication.

\section{Study population and questionnaire}

The Frankfurt University Hospital is a 1,169-bed hospital with approximately 3,900 employees including 726 physicians, 1,300 nurses and 850 medical technicians. It has approximately 42,000 in-patient admissions and about 200,000 out-patients per year. At the Frankfurt Medical School, which is organisationally within the Frankfurt University Hospital, there are approximately 3,300 medical and dental students, including 1,200 medical students who are in the clinical phase of their studies. A comprehensive influenza vaccination campaign, which included publicity (posters, leaflets), education (information sessions), and vaccination started in the influenza season 2003/04. Influenza vaccination as well as advice to HCWs is offered by the occupational health service of the university hospital. In the past seven years we achieved an improvement in seasonal influenza vaccination uptake from $3.2 \%$ in $2002 / 03$ to $40.5 \%$ in $2009 / 10$.

To address why higher vaccination uptakes were not met during the pandemic 2009/10, we developed a questionnaire for 2010/11, after reviewing published studies on reasons why HCWs accept or refuse influenza vaccination and after conducting a preliminary survey one week before the vaccination campaign with $20 \mathrm{HCWs}$. The final questionnaire comprised seven closed questions divided into three areas: demographic data (age, sex, profession group, field of work), acceptance of the pandemic influenza $A\left(\mathrm{H}_{1} \mathrm{~N}_{1}\right)_{2009}$ vaccination in $2009 / 10$, and attitudes in response to the pandemic. HCWs and medical students who came to get the seasonal influenza vaccine between October 2010 and February 2011 were asked to complete this anonymous self-administered questionnaire and to return it in a locked box.

\section{Ethical considerations}

Participants were informed that all the information gathered would be anonymous and kept confidential. Participation was voluntary, completion of the questionnaire implied consent for study participation. Participants cannot be identified from the material presented.

\section{Statistical analysis}

The statistical analysis of the frequency distributions was done using a two-tailed Pearson's chi-square test. The threshold $p$-value for statistical significance was set to $p<0.05$. The questionnaire was not based on a priori hypotheses; nevertheless, an a-adjustment was made with 14 and five four-field tables, using the Bonferroni post-test which considered selective (local) p-values of

\section{TABLE 1}

Demographic characteristics of participants, healthcare workers and medical students at Frankfurt University Hospital, October 2010-February $2011(n=1,645)$

\begin{tabular}{|c|c|c|}
\hline Age (years) & $\mathrm{n}$ & $\%$ \\
\hline Up to 30 & 648 & 39.4 \\
\hline $31-40$ & 434 & 26.4 \\
\hline $41-50$ & 337 & 20.5 \\
\hline $51-60$ & 191 & 11.6 \\
\hline Over 60 & 35 & 2.1 \\
\hline \multicolumn{3}{|l|}{ Sex } \\
\hline Male & 663 & 40.3 \\
\hline Female & 982 & $59 \cdot 7$ \\
\hline \multicolumn{3}{|l|}{ Job description } \\
\hline Physicians & 505 & 30.7 \\
\hline Medical students & 322 & 19.6 \\
\hline Nurses & 394 & 23.9 \\
\hline Medical technicians & 104 & 6.3 \\
\hline Administrative personnel & 164 & 10.0 \\
\hline Maintenance, catering, workshop, transport & 77 & $4 \cdot 7$ \\
\hline Others & 79 & 4.8 \\
\hline \multicolumn{3}{|l|}{ Field of work } \\
\hline Anaesthesia & 144 & 8.8 \\
\hline Ophthalmology & 24 & 1.5 \\
\hline Surgery & 118 & 7.2 \\
\hline Dermatology & 48 & 2.9 \\
\hline Gynaecology & 53 & 3.2 \\
\hline Ear, nose and throat & 20 & 1.2 \\
\hline Internal Medicine & 338 & 20.5 \\
\hline Psychiatry & 53 & 3.2 \\
\hline Paediatrics & 145 & 8.8 \\
\hline Radiology & 74 & $4 \cdot 5$ \\
\hline Neurology & 86 & 5.2 \\
\hline Other department or not specified & 542 & 32.9 \\
\hline
\end{tabular}


$\mathrm{p} \leq 0.0036$ (Table 2) and $\mathrm{p} \leq 0.01$ (Table 3 ) as statistically significant at the global overall significance level of $a=0.05$. The significance calculations were made using the program BiAS for Windows 9.04 (Epsilon Verlag, Hochheim Darmstadt 2009). Furthermore, 95\% confidence intervals $(\mathrm{Cl})$ were calculated.

\section{Results}

From October 2010 to February 2011, 1,366 of 3,900 (35.0\%) HCWs of the University Hospital Frankfurt were vaccinated with the seasonal trivalent influenza vaccine. In total, 1,323 vaccinated HCWs (response rate $96.9 \%)$ and 322 of $1,200(26.8 \%)$ medical students in the clinical phase of their studies at the Frankfurt Medical School completed the anonymous questionnaire and were vaccinated against influenza. All 1,645 questionnaires could be analysed. Overall 982 of 1,645 (59.7\%) participants were female, and 663 of 1,645 ( $40.3 \%)$ were male, in accordance with the sex distribution of employees and student body at the university. Demographic characteristics of the study population are shown in Table 1.

\section{TABLE 2}

Healthcare workers reasons for refusing the AS03 adjuvanted pandemic influenza vaccine in the 2009/10 influenza season, Frankfurt University Hospital, October 2010-February $2011(\mathrm{n}=1,645)$

\begin{tabular}{|c|c|c|c|c|c|c|}
\hline Reason & $\begin{array}{l}\text { Total persons } \\
(\mathrm{n}=712) \\
\text { number } \\
\text { percentage } \\
(95 \% \mathrm{Cl})\end{array}$ & $\begin{array}{l}\text { Physicians } \\
(\mathrm{n}=100) \\
\text { number } \\
\text { percentage } \\
(95 \% \mathrm{Cl})\end{array}$ & $\begin{array}{c}\text { Nurses } \\
(\mathrm{n}=202) \\
\text { number } \\
\text { percentage } \\
(95 \% \mathrm{Cl})\end{array}$ & $\begin{array}{l}\text { Physicians vs nurses } \\
\text { p value }\end{array}$ & $\begin{array}{c}\text { Students } \\
(\mathrm{n}=192) \\
\text { number } \\
\text { percentage } \\
(95 \% \mathrm{Cl})\end{array}$ & $\begin{array}{c}\text { Others } \\
(\mathrm{n}=218) \\
\text { number } \\
\text { percentage } \\
(95 \% \mathrm{Cl})\end{array}$ \\
\hline No personal risk of contracting influenza & $\begin{array}{c}238 \\
33.4 \% \\
(30.0-37.0) \\
\end{array}$ & $\begin{array}{c}27 \\
27.0 \% \\
(18.6-36.8) \\
\end{array}$ & $\begin{array}{c}47 \\
23 \cdot 3 \% \\
(17.7-29 \cdot 7) \\
\end{array}$ & 0.478 & $\begin{array}{c}89 \\
46.4 \% \\
(39.1-53.7) \\
\end{array}$ & $\begin{array}{c}75 \\
34.4 \% \\
(28.1-41.1) \\
\end{array}$ \\
\hline No severity of influenza illness & $\begin{array}{c}96 \\
13.5 \% \\
(11.1-16.2)\end{array}$ & $\begin{array}{c}12 \\
12.0 \% \\
(6.4-20.0)\end{array}$ & $\begin{array}{c}21 \\
10.4 \% \\
(6.6-15 \cdot 5) \\
\end{array}$ & 0.674 & $\begin{array}{c}33 \\
17.2 \% \\
(12.1-23 \cdot 3)\end{array}$ & $\begin{array}{c}30 \\
13.8 \% \\
(9.5-19.1) \\
\end{array}$ \\
\hline Vaccine does not work & $\begin{array}{c}86 \\
12.1 \% \\
(9 \cdot 3-14 \cdot 7) \\
\end{array}$ & $\begin{array}{c}11 \\
11.0 \% \\
(5.6-18.8) \\
\end{array}$ & $\begin{array}{c}22 \\
10.9 \% \\
(7.0-16.0) \\
\end{array}$ & 0.977 & $\begin{array}{c}31 \\
16.1 \% \\
(11.2-22.1) \\
\end{array}$ & $\begin{array}{c}22 \\
10.1 \% \\
(6.4-14.9) \\
\end{array}$ \\
\hline Fear of side effects & $\begin{array}{c}187 \\
26.3 \% \\
(23.0-29.7)\end{array}$ & $\begin{array}{c}25 \\
25.0 \% \\
(16.9-34.7)\end{array}$ & $\begin{array}{c}66 \\
32.7 \% \\
(26.3-39.6)\end{array}$ & 0.171 & $\begin{array}{c}43 \\
22.4 \% \\
(16.7-29.0)\end{array}$ & $\begin{array}{c}53 \\
24.3 \% \\
(18.8-30.6)\end{array}$ \\
\hline Fear of adjuvants & $\begin{array}{c}239 \\
33.6 \% \\
(30.1-37.2) \\
\end{array}$ & $\begin{array}{c}35 \\
35.0 \% \\
(25.7-45.2) \\
\end{array}$ & $\begin{array}{c}83 \\
41.1 \% \\
(34.2-48.2) \\
\end{array}$ & 0.307 & $\begin{array}{c}47 \\
24 \cdot 5 \% \\
(18.6-31.2) \\
\end{array}$ & $\begin{array}{c}74 \\
33.9 \% \\
(27.7-40.6) \\
\end{array}$ \\
\hline Fear of needles & $\begin{array}{c}11 \\
1.5 \% \\
(0.8-2.7) \\
\end{array}$ & $\begin{array}{c}1 \\
1.0 \% \\
(0.0-5.4) \\
\end{array}$ & $\begin{array}{c}6 \\
3.0 \% \\
(1.1-6.4) \\
\end{array}$ & 0.284 & $\begin{array}{c}0 \\
0 \% \\
(0.0-1.5) \\
\end{array}$ & $\begin{array}{c}4 \\
1.8 \% \\
(0.5-4.6) \\
\end{array}$ \\
\hline Vaccine causes flu & $\begin{array}{c}28 \\
3.9 \% \\
(2.6-5.6) \\
\end{array}$ & $\begin{array}{c}3 \\
3.0 \% \\
(0.1-8.5) \\
\end{array}$ & $\begin{array}{c}15 \\
7.4 \% \\
(4.2-12.0) \\
\end{array}$ & 0.126 & $\begin{array}{c}3 \\
1.5 \% \\
(0.3-4.5) \\
\end{array}$ & $\begin{array}{c}7 \\
3.2 \% \\
(1.3-6.5) \\
\end{array}$ \\
\hline No time - too busy & $\begin{array}{c}52 \\
7 \cdot 3 \% \\
(5 \cdot 5-9 \cdot 5)\end{array}$ & $\begin{array}{c}12 \\
12.0 \% \\
(6.4-20.0)\end{array}$ & $\begin{array}{c}7 \\
3.5 \% \\
(1.4-7.0)\end{array}$ & 0.004 & $\begin{array}{c}19 \\
9.9 \% \\
(6.1-15.0)\end{array}$ & $\begin{array}{c}14 \\
6.4 \% \\
(3.6-10.5) \\
\end{array}$ \\
\hline Forgotten & $\begin{array}{c}36 \\
5.1 \% \\
(3.6-6.9) \\
\end{array}$ & $\begin{array}{c}6 \\
6.0 \% \\
(2.2-12.6) \\
\end{array}$ & $\begin{array}{c}8 \\
4.0 \% \\
(1.7-7.7) \\
\end{array}$ & 0.428 & $\begin{array}{c}12 \\
6.3 \% \\
(3.3-10.7) \\
\end{array}$ & $\begin{array}{c}10 \\
4.6 \% \\
(2.2-8.3) \\
\end{array}$ \\
\hline Missed vaccination days at the hospital & $\begin{array}{c}31 \\
4.4 \% \\
(3.0-6.1) \\
\end{array}$ & $\begin{array}{c}7 \\
7.0 \% \\
(2.9-13.9) \\
\end{array}$ & $\begin{array}{c}7 \\
3.5 \% \\
(1.4-7.0) \\
\end{array}$ & 0.169 & $\begin{array}{c}10 \\
5.2 \% \\
(2.5-9.4) \\
\end{array}$ & $\begin{array}{c}7 \\
3.2 \% \\
(1.3-6.5) \\
\end{array}$ \\
\hline Media hype alienated me & $\begin{array}{c}104 \\
14.6 \% \\
(12.1-17.4) \\
\end{array}$ & $\begin{array}{c}7 \\
7.0 \% \\
(2.9-13.9)\end{array}$ & $\begin{array}{c}32 \\
15.8 \% \\
(11.1-21.6) \\
\end{array}$ & 0.031 & $\begin{array}{c}21 \\
10.9 \% \\
(6.9-16.2) \\
\end{array}$ & $\begin{array}{c}44 \\
20.2 \% \\
(15.1-26.1) \\
\end{array}$ \\
\hline Insufficient information about vaccine & $\begin{array}{c}38 \\
5.3 \% \\
(3.8-7.3) \\
\end{array}$ & $\begin{array}{c}5 \\
5.0 \% \\
(1.6-11.3) \\
\end{array}$ & $\begin{array}{c}10 \\
5.0 \% \\
(2.4-8.9) \\
\end{array}$ & 0.985 & $\begin{array}{c}14 \\
7.3 \% \\
(4.0-11.9) \\
\end{array}$ & $\begin{array}{c}9 \\
4.1 \% \\
(1.9-7.7) \\
\end{array}$ \\
\hline GP advised against pandemic vaccine & $\begin{array}{c}46 \\
6.5 \% \\
(4.8-8.5) \\
\end{array}$ & $\begin{array}{c}2 \\
2.0 \% \\
(0.2-7.0) \\
\end{array}$ & $\begin{array}{c}13 \\
6.4 \% \\
(3.5-10.8) \\
\end{array}$ & 0.095 & $\begin{array}{c}10 \\
5.2 \% \\
(2.5-9.4) \\
\end{array}$ & $\begin{array}{c}21 \\
9.6 \% \\
(6.1-14 \cdot 3) \\
\end{array}$ \\
\hline Got no appointment with GP & $\begin{array}{c}3 \\
0.4 \% \\
(0.1-1.2)\end{array}$ & $\begin{array}{c}0 \\
0 \% \\
(0.0-2.9)\end{array}$ & $\begin{array}{c}1 \\
0.5 \% \\
(0.0-2.7)\end{array}$ & 0.481 & $\begin{array}{c}2 \\
1.0 \% \\
(0.1-3.7)\end{array}$ & $\begin{array}{c}0 \\
0 \% \\
(0.0-1.4)\end{array}$ \\
\hline
\end{tabular}

$\mathrm{Cl}$ : confidence interval; GP: general practitioner.

Multiple answers were possible and 1,195 answers were provided. Overall $43.3 \%$ ( 712 of 1,645 ) of the participants of the study were not vaccinated with the pandemic vaccine. 
When asked how much time the participants provided care to immunocompromised patients (i.e. haematology, oncology, intensive-care units), 576 (35\%) of the respondents stated daily, 411 (25\%) occasionally, and $658(40 \%)$ never.

Of all respondents, $933(56.7 \%)$ stated that they had been vaccinated with the ASo3-adjuvanted pandemic vaccine in the 2009/10 influenza season. The 712 (43.3\%) respondents who had not received this vaccine were asked to provide the reasons for this. The main reason for not getting vaccinated was the objection to the ASo3 adjuvants (239/712, 33.6\%), closely followed by the belief that they personally were unlikely to catch influenza $(238 / 712,33.4 \%)$ (Table 2). Regarding these two frequently mentioned reasons there was no significant difference between physicians and nurses $(p=0.352)$ (Table 2$)$ or between women and men $(p=0.426)$. No significant differences ( $p<0.05)$ in answers to all 14 questions stated in Table 2 could be seen between HCWs who were in daily contact with immunocompromised patients $(165 / 712,23.2 \%)$ and HCWs with occasional or no contact with such patients. However, men $(45 / 246,18.3 \%)$ stated more often than women $(51 / 466,10.9 \%)$ that they did not get vaccinated with the pandemic vaccine because they did not perceive the influenza $A\left(\mathrm{H}_{1} \mathrm{~N}_{1}\right) 2009$ virus infection as a severe disease $(p=0.006)$. On the other hand more women $(137 / 466,29.4 \%)$ than men $(50 / 246,20.3 \%)$ noted that they had refused the pandemic vaccine because they had feared side effects $(p=0.009)$.

Of the 1,645 HCWs surveyed, $270(16.4 \%)$ cited that the 2009 influenza $A\left(\mathrm{H}_{1} \mathrm{~N}_{1}\right)$ pandemic influenced their attitudes towards vaccination in general (Table 3 ). Nurses $(59 / 87,67.8 \%)$ stated more often than physicians $(36 / 73,49.3 \%)$ that due to the pandemic it became clear that influenza is a severe disease $(p=0.018)$, and also more nurses $(21 / 87,24.1 \%)$ than physicians $(8 / 73$, $11.0 \%)$ noted that they were concerned owing to the media hype $(p=0.031)$. Otherwise, physicians stated more often than nurses ( $43.8 \%$ versus $25.3 \%$ ) that they had had a positive experience with reference to the influenza vaccination $(p=0.013)$ (Table 3$)$.

\section{Discussion}

Increasing the public's acceptance of the influenza vaccination might be more challenging than addressing the scientific challenges involved in producing a safe and effective influenza vaccine [14]. Because a large number of people refuse to be vaccinated, it is important to understand the attitudes of the public and HCWs towards influenza vaccination [14]. It is therefore not enough to provide a safe vaccine, one also needs to convince the public to accept it. We attempted to understand the reasons of HCWs for not accepting the pandemic influenza $A\left(\mathrm{H}_{1} \mathrm{~N}_{1}\right) 2009$ vaccine as well as the impact of the pandemic on attitudes toward influenza infection.

The study showed that many German HCWs were unconvinced of the safety of the pandemic influenza vaccine. Fear of adjuvants was the most common reason cited for refusal of the adjuvanted pandemic vaccine. Since the 18th century, fear and mistrust have arisen every time a new vaccine has been introduced [17]. For this reason, communication is an issue which requires constant improvement. The media plays an

\section{TABLE 3}

Changes in attitudes following the emergence of pandemic influenza A(H1N1)2009, healthcare workers at Frankfurt University Hospital, October 2010-February $2011(\mathrm{n}=270)$

\begin{tabular}{|c|c|c|c|c|c|c|}
\hline & $\begin{array}{l}\text { Total persons } \\
(\mathrm{n}=270) \\
\text { number } \\
\text { percentage } \\
(95 \% \mathrm{Cl})\end{array}$ & $\begin{array}{c}\text { Physicians } \\
(\mathrm{n}=73) \\
\text { number } \\
\text { percentage } \\
(95 \% \mathrm{Cl})\end{array}$ & $\begin{array}{c}\text { Nurses } \\
(\mathrm{n}=87) \\
\text { number } \\
\text { percentage } \\
(95 \% \mathrm{Cl})\end{array}$ & $\begin{array}{l}\text { Physicians vs } \\
\text { nurses } \\
\text { p value }\end{array}$ & $\begin{array}{l}\text { Students } \\
(\mathrm{n}=40) \\
\text { number } \\
\text { percentage } \\
(95 \% \mathrm{Cl})\end{array}$ & $\begin{array}{c}\text { Others } \\
(\mathrm{n}=70) \\
\text { number } \\
\text { percentage } \\
(95 \% \mathrm{Cl})\end{array}$ \\
\hline $\begin{array}{l}\text { Pandemic created awareness for immunisati- } \\
\text { ons and caused me to check my vaccination } \\
\text { card }\end{array}$ & $\begin{array}{c}51 \\
18.9 \% \\
(14.4-24.1) \\
\end{array}$ & $\begin{array}{c}20 \\
27.4 \% \\
(17.6-39.1) \\
\end{array}$ & $\begin{array}{c}9 \\
10.3 \% \\
(4.8-18.7) \\
\end{array}$ & 0.010 & $\begin{array}{c}17 \\
42.5 \% \\
(27.4-59.1) \\
\end{array}$ & $\begin{array}{c}5 \\
7.1 \% \\
(23.6-15 \cdot 9) \\
\end{array}$ \\
\hline $\begin{array}{l}\text { I had a positive experience with the influenza } \\
\text { vaccination, therefore I am going to get vacci- } \\
\text { nated every year }\end{array}$ & $\begin{array}{c}84 \\
31.1 \% \\
(25.6-37.0) \\
\end{array}$ & $\begin{array}{c}32 \\
43.8 \% \\
(32.2-55.9) \\
\end{array}$ & $\begin{array}{c}22 \\
25 \cdot 3 \% \\
(16.6-35 \cdot 7)\end{array}$ & 0.013 & $\begin{array}{c}8 \\
20.0 \% \\
(9.1-35.6) \\
\end{array}$ & $\begin{array}{c}22 \\
31.4 \% \\
(20.9-43.6) \\
\end{array}$ \\
\hline $\begin{array}{l}\text { Media hype alienated me and lowered my } \\
\text { confidence in vaccination policies }\end{array}$ & $\begin{array}{c}50 \\
18.5 \% \\
(14.1-23 \cdot 7) \\
\end{array}$ & $\begin{array}{c}8 \\
11.0 \% \\
(4.8-20.5) \\
\end{array}$ & $\begin{array}{c}21 \\
24.1 \% \\
(15 \cdot 6-34 \cdot 5) \\
\end{array}$ & 0.031 & $\begin{array}{c}1 \\
2.5 \% \\
(0.1-13.2) \\
\end{array}$ & $\begin{array}{c}20 \\
28.6 \% \\
(18.4-40.6) \\
\end{array}$ \\
\hline $\begin{array}{l}\text { Having heard a lot about adjuvanted vaccines } \\
\text { and side effects, I became sceptical towards } \\
\text { vaccinations }\end{array}$ & $\begin{array}{c}61 \\
22.6 \% \\
(17.7-28.1)\end{array}$ & $\begin{array}{c}13 \\
17.8 \% \\
(9.8-28.5)\end{array}$ & $\begin{array}{c}19 \\
21.8 \% \\
(13.7-32.0)\end{array}$ & 0.526 & $\begin{array}{c}7 \\
17.5 \% \\
(7.3-32.8) \\
\end{array}$ & $\begin{array}{c}22 \\
31.4 \% \\
(20.9-43.6)\end{array}$ \\
\hline
\end{tabular}

$\mathrm{Cl}$ : confidence interval.

Multiple answers were possible; 394 answers about risk perception were provided. Overall $16.4 \%$ (270 of 1,645) of the participants stated that the influenza $\mathrm{A}\left(\mathrm{H}_{1} \mathrm{~N}_{1}\right) 2009$ pandemic influenced their attitudes towards vaccination in general. 
important role in translating scientific information and in shaping the public's understanding of health issues and risk perception of infectious diseases [18]. Greater efforts in educating the public and HCWs about influenza vaccine safety and the benefits of vaccination are needed for an effective public health response [13].

To appreciate the results of our study, some potential limitations need to be addressed: Firstly, results from a single German academic institution may not be applicable to other institutions. Secondly, given that we only questioned HCWs who received the 2010/11 seasonal influenza vaccination, it is possible that HCWs who were not willing to get vaccinated may have had other reasons to decline the adjuvanted pandemic influenza vaccine. Thirdly, the social desirability bias, i.e. selecting a choice of answers considered as being socially most favourable may have lead to bias in our survey. Fourthly, it would have been interesting to compare the reasons to accept the seasonal influenza vaccination with the reasons for accepting or declining pandemic influenza immunisation. Unfortunately, we did not survey this in the present study.

For infectious diseases that potentially have a large impact on public health, risk communication is a particular challenge. Providing the public and HCWs with relevant information about an outbreak could decrease levels of concern by reducing levels of uncertainty about the nature, prevention or treatment of the infectious disease [19]. It is important to identify the most appropriate type of information which can be understood and trusted.

Problems along the way include the unacceptably low influenza vaccination rates amongst HCWs for more than three decades despite official vaccination recommendations $[11,20]$, and the perception of the $\mathrm{H}_{1} \mathrm{~N}_{1} / 2009$ pandemic on behalf of the public that boarders ignorance and hysteria [21,22]. It has to be communicated better that HCWs who do not get vaccinated are taking two risks: firstly, the risk of themselves contracting influenza, a potentially long and serious illness, and secondly, the risk of transmitting influenza to their patients. Patients have a right to expect that HCWs and the institutions in which they work will take all necessary and reasonable precautions to keep them safe and minimise harm. The healthcare system will have to define a strategy to reach a sufficient influenza vaccination coverage among HCWs $[11,16]$.

In conclusion, many German HCWs were unconvinced of the safety of the adjuvanted influenza vaccine. Greater efforts to educate HCWs about influenza vaccine safety and the need to increase influenza vaccination rates to ensure patient safety are of the utmost importance.
Acknowledgments

The authors would like to thank the participants of the study for their time and effort in completing the questionnaire and their valuable suggestions regarding the project.

\section{Conflict of interest}

The views in this article are the personal views of the authors and do not necessarily represent the views of the professional organizations or institutions within which we are members.

Sabine Wicker is a member of the German Standing Committee on Vaccination (STIKO) at the Robert Koch Institute (RKI). She has been a member of an advisory board on nasal influenza vaccines for AstraZeneca Germany. She has received honoraria for non-product-related talks on influenza vaccination from GlaxoSmithKline, Sanofi Pasteur, and Novartis.

\section{References}

1. Blachere FM, Lindsley WG, Pearce TA, Anderson SE, Fisher M, Khakoo R. et al. Measurement of airborne influenza virus in a hospital emergency department. Clin Infect Dis. 2009;48(4):438-40.

2. Mermel LA. Preventing the spread of influenza $\mathrm{A} \mathrm{H}_{1} \mathrm{H}_{1} 2009$ to health-care workers. Lancet Infect Dis. 2009;9(12):723-4.

3. Wicker S, Rabenau HF, Bickel M, Wolf T, Brodt R, Brandt $C$, et al. Novel Influenza $\mathrm{H}_{1} \mathrm{~N}_{1} / 2009$ : virus transmission among health care worker. Dtsch Med Wochenschr. 2009;134(48):2443-6. German.

4. Poland GA, Tosh P, Jacobson RM. Requiring influenza vaccination for health care workers: seven truths we must accept. Vaccine. 2005;23(17-18):2251-5.

5. European Union. Council Recommendation of 22 December 2009 on seasonal influenza vaccination. Official Journal of the European Union. 2009;L348:71-2.

6. Ofstead CL, Tucker SJ, Beebe TJ, Poland GA. Influenza vaccination among registered nurses: information receipt, knowledge, and decision-making at an institution with a multifaceted educational program. Infect Control Hosp Epidemiol. 2008;29(2):99-106.

7. Talbot TR. Improving rates of influenza vaccination among healthcare workers: educate; motivate; mandate? Infect Control Hosp Epidemiol. 2008;29(2):107-10.

8. Looijmans-van den Akker I, van Delden JJM, Verheij TJM Van Essen GA, van der Sande MA, Hulscher ME, et al. Which determinants should be targeted to increase influenza vaccination uptake among health care workers in nursing homes? Vaccine. 2009;27(34):4724-30.

9. Wicker S, Rabenau HF. The reluctance of nurses to get vaccinated against influenza. Vaccine. 2010;28(29):4548-9.

10. Hollmeyer HG, Hayden F, Poland GA, Buchholz U. Influenza vaccination of health care workers in hospitals - a review of studies on attitudes and predictors. Vaccine. 2009;27(30):3935-44

11. Ottenberg AL, Wu JT, Poland GA, Jacobson RM, Koenig BA, Tilburt JC. Vaccinating health care workers against influenza: the ethical and legal rationale for a mandate. Am J Public Health. 2011;101(2):212-6.

12. Nichol KL, Lind A, Margolis KL, Murdoch M, McFadden R, Hauge $M$, et al. The effectiveness of vaccination against influenza in healthy, working adults. N Engl Med. 1995;333(14):889-93.

13. Poland GA. Pandemic 2009-2010 influenza vaccine: Six lessons learned and the way forward (allegro not Adagio). Vaccine. 2011;29(4):613-4.

14. Harris KM, Maurer J, Kellermann AL. Influenza Vaccine - Safe, Effective, and Mistrusted. N Engl J Med. 2010;363(23):2183-5.

15. Sullivan SJ, Jacobson RM, Dowdle WR, Poland GA. $2009 \mathrm{H}_{1} \mathrm{~N}_{1}$ Influenza. Mayo Clin Proc. 2010;85(1):64-76.

16. McLennan $S$, Wicker $S$. Reflections on the influenza vaccination of healthcare workers. Vaccine. 2010;28(51):8061-4.

17. Poland GA, Jacobson RM. The age-old struggle against the antivaccinationists. N Engl J Med. 2011;364(2):97-9. 
18. Hilton S, Hunt K. UK newspapers' representations of the 200910 outbreak of swine flu: one health scare not over-hyped by the media? J Epidemiol Community Health. Forthcoming 2010 Dec 3.

19. Dickmann P, Rubin GJ, Gaber W, Wessely S, Wicker S, Serve H, et al. New influenza $A / \mathrm{H}_{1} \mathrm{~N}_{1}$ ("swine flu"”): information needs of airport passengers and staff. Influenza Other Respi Viruses. 2011;5(1):39-46.

20. Wicker S, Rabenau HF, Gottschalk R, Krause G, McLennan S. Low influenza vaccination rates among healthcare workers. Time to take a different approach. Bundesgesundheitsblatt Gesundheitsforschung Gesundheitsschutz. 2010;53(12):1298 303.German.

21. Ofri D. The emotional epidemiology of $\mathrm{H}_{1} \mathrm{~N}_{1}$ influenza vaccination. N Engl J Med. 2009;361(27):2594-5.

22. 22. Goodwin R, Haque S, Neto F, Myers L. Initial psychological responses to Influenza A, H1N1 ("Swine flu"). BMC Infect Dis. 2009;9:166. 